\title{
Factors Determining Acquisitions of Companies in Slovenia*
}

\author{
Matej Lahovnik $^{* *}$
}

This paper deals with some specific characteristics of the acquisition strategy in the Slovenian economy. Some characteristics cannot be compared with Western European developed economies; such characteristics include the incomplete privatisation process, the underdeveloped financial and labour markets and certain structural changes. The purpose of this paper is to highlight these characteristics and to reveal some main factors that motivate the companies to develop the strategy of acquisition in the Slovenian economy in its transition period. In this paper the results of the empirical research into factors determining the acquisitions in Slovenia are to be presented. The respondents were managing directors of 62 large Slovenian enterprises. The basic statistical measure is weighted average. The dispersion of the assessment is described by calculating standard deviation.

Dieser Artikel setzt sich mit einigen spezifischen Merkmalen der Übernahmestrategien in Slowenien auseinander. Einige dieser Merkmale koennen jedoch nicht mit dem westeuropaeischen Wirtschaftsraumverglichen werden: z.B. dem Privatizationsprozess und den bestimmten strukturellen Änderungen. Dem Artikel liegt die Absicht zugrunde, spezifische Merkmale der Übernahmestrategien in Slowenien zu definieren und Motive fuer die Firmenübernahme im slowenischen Wirtschaftsraum festzulegen, und zwar in der Zeitspanne des Transitionsprozesses. Die Ergebnisse basieren auf der Befragung von Geschäftsführern von 62 Großfirmen. Als statistisches Maß gilt der gewichtete Durchschnitt. Die Dispersion der Bewertung ist durch die Standarddeviation ausgemessen.

\footnotetext{
* manuscript received: 30.6.1999, revised: 13.3.2000, accepted: 15.3.2000;

** Matej Lahovnik, born 1971, is research and teaching assistant and a $\mathrm{PhD}$ candidate at the Faculty of Economics in Ljubljana. His research topics are Strategic factors of the Acquisition Strategies in the Economies in Transition.
} 


\section{Introduction}

Mergers, acquisitions, restructuring, and corporate control issues have become central public and corporate policy issues in developed economies. The acquisition of enterprises have become the most popular corporate strategy in global industries. In the future, shifts in the levels of acquisition activities may occur with fluctuations in the economies and with changing regulatory environments. However, the integration of local markets into the global economy, the development of financial markets, the liberalisation and deregulation processes strongly support the thesis that mergers and acquisitions will continue to be major forces in the economy.

We have been faced with some specific characteristics of the acquisition strategy in the Slovenian economy, that cannot be compared with Western European developed economies; such characteristics include the incomplete privatisation process, the underdeveloped financial and labour markets and certain structural changes. The purpose of this paper is to highlight these characteristics and to reveal some main factors that motivate the companies to develop the strategy of acquisition in the Slovenian economy in its transition period. On the basis of different research, motives for developing the acquisition strategy are also compared. In this paper the results of the empirical research into factors determining the acquisitions in Slovenia are to be presented. The empirical research is based on an extensive questionnaire and it is a part of the Behaviour of the Slovenian Enterprises in the Transition Period project. The survey was mailed to the top managers of 150 large Slovenian companies regarding sale and number of the employees. Of the 150 surveys mailed, 62 were returned, giving a response rate of $41,3 \%$. The basic statistical measure is weighted average. The dispersion of the assessment is described by calculating standard deviation.

\section{Reasons for the increasing importance of mergers and acquisition in the world economy}

Four factors have contributed to increased diversification of business firms (Weston et al., 1990, p.76): the revolution that has taken place in management technology since World War II, the increased pace of technological change, the higher fixed costs of management-staff services and changes in the equity markets which have reinforced these other factors.

Diversification into unrelated businesses during the 1960s was based on the assumption that good managers could manage any business. This resulted in the formation of huge conglomerates of completely unrelated businesses. In the 1970s, diversification was based on the portfolio approach. Corporate managers attempted to diversify in such a way that the resulting portfolio offered a balance between businesses that produced excess cash flows and those needed additional cash flows beyond what they could produce themselves. In the 1980s, there was 
an effort to restructure corporations by divesting unrelated businesses and to focus on a narrower range of operations. In the 1990s, we have been faced with the increasing importance of diversification strategy. Human resources have become one of the most important distinctive competencies of corporations. On the other hand, the economies derived by spreading the fixed costs of managerial staff and specialist functions over a wide range of activities have increased. Therefore, small firms have difficulties in attracting management with a full range of abilities. Because many staff and specialist functions are applicable in different types of industries, a further acceleration to diversification process can be identified.

Some reasons for the dramatic increase in the volume of acquisitions therefore include:

- a more deregulated environment and the growing influence of arbitrages,

- the need to combine business activities on the global level to increase competitive potential,

- the increasing importance of human resource capital that can be acquired through acquisitions,

- more efficient resource allocation through acquisitions,

- increasing international competition in global and local markets,

- a greater competition among merchant banks, which desire to strengthen their position in global markets and their willingness to lend cash for acquisitions as an entry point to corporate clients,

- the increasing importance of pension fund managers, under pressure for short term importance, and therefore liable to be attracted by the share- price gains generated by bids,

- the increasing importance of brand names that new ones could be very difficult and expensive to establish.

We can broadly define three forms of diversification: horizontal, vertical and global and three means of achieving it: acquisition, strategic alliances and internal development.

\section{Specific characteristics of slovenia's business environment}

\subsection{Basic characteristics of Slovenian economy}

The Slovenian Economy has had some advantages because of the positive legacy of its Yugoslavian past which gave Slovene companies a sizeable head start over the rest of the Central-Eastern European Region when it came into transition. Slovene enterprises have been exposed to the market economy for decades and have had traditional trade links with Western European companies. 
They exported goods at dumping prices in order to earn hard currency for imports and on the other hand sold goods on the protected Yugoslavian markets at higher prices than those that would be earned on external markets. When Slovenia became an independent state in 1991, it lost the huge Yugoslavian market and Slovenian firms were forced to implement restructuring processes.

Slovenia has been faced with the triple transition process: the transition to an independent state, the reorientation from former Yugoslavian to the Western developed markets and the transition to the market economy. Slovenian industry has succeeded in finding substitute markets. Economic growth has been steady since 1993 (See Table 1). The most positive developments during this transition period have been: the decreasing inflation rate, the stabilisation of the exchange rate and the increase in foreign exchange reserves. Declining industrial production and an increase in unemployment have been major negative trends in the first period of transition 1991-1994. However we may conclude that the basic economic trends are now positive.

Table 1: Some Economic Trends of the Slovenian Economy in the Transition Period

\begin{tabular}{|l|c|c|c|c|c|c|c|}
\hline Category & $\begin{array}{c}\text { Year } \\
\mathbf{1 9 9 2}\end{array}$ & $\begin{array}{l}\text { Year } \\
\mathbf{1 9 9 3}\end{array}$ & $\begin{array}{l}\text { Year } \\
\mathbf{1 9 9 4}\end{array}$ & $\begin{array}{l}\text { Year } \\
\mathbf{1 9 9 5}\end{array}$ & $\begin{array}{l}\text { Year } \\
\mathbf{1 9 9 6}\end{array}$ & $\begin{array}{c}\text { Year } \\
\mathbf{1 9 9 7}\end{array}$ & $\begin{array}{c}\text { Year } \\
\mathbf{1 9 9 8}\end{array}$ \\
\hline $\begin{array}{l}\text { Real growth of } \\
\text { the GDP (\%) }\end{array}$ & -5.5 & 2.8 & 5.3 & 4.1 & 3.1 & 3.8 & 3.9 \\
\hline $\begin{array}{l}\text { Consumer } \\
\text { price index }\end{array}$ & - & 132.9 & 121 & 113.5 & 109.9 & 108.4 & 107.9 \\
\hline $\begin{array}{l}\text { GDP per } \\
\text { capita (USD) }\end{array}$ & 6,275 & 6,366 & 7,233 & 9,431 & 9,471 & 9,163 & 9,864 \\
\hline $\begin{array}{l}\text { Real growth of } \\
\text { the wages }\end{array}$ & - & 13.3 & 3.6 & 4.4 & 4.9 & 3.2 & 1.6 \\
\hline $\begin{array}{l}\text { Trade with } \\
\text { EU* }\end{array}$ & 66.7 & 63.1 & 67.6 & 68.1 & 66.2 & 68.3 & 67.5 \\
\hline
\end{tabular}

* EU trade as a share of total merchandise trade; Source: Bilten BS, 1998, p. 68, Ekonomsko ogledalo, 1997, p. 14, 1999, p. 15

While around 130,000 jobs were lost during the restructuring process of large companies, the number of SME's (defined as having fewer than 250 employees) has more than doubled since 1989 and employment in this sector has grown by $400 \%$. It now accounts for over $53 \%$ of total employment and $58 \%$ of sales. On the other hand, more than two thirds of all small businesses have one or no employees, and the average number is less than five. Three quarters of the all SME's are in the service sector. In the year 1997, 85.6 percent of Slovenian 
firms had less than 20 employees, 6.1 percent had between 20 and 50 employees, 3.8 percent had between 50 and 100 employees, 2.5 percent between 100 and 200 employees, and 1.4 percent of firms had between 200 and 500 employees, whereas only 0.6 percent of firms had more than 500 employees (Statistical Yearbook RS, 1997, p.62).

Relations with Western trading partners often developed into licensing and cooperation agreements that have enabled many Slovenian companies to obtain modern technology. Slovenian companies penetrated foreign markets under their own trademarks by buying basic technology licenses to develop their own brand name products. In the transition period they succeeded in maintaining these relation. Even more, Pučko, in his research, found that many large Slovenian enterprises had applied some kind of subcontracting strategy during the first three years of transition (Pučko et al., 1996, p. 470). From 1991-1993, 39.6\% of enterprises began subcontracting relationships, $81.8 \%$ of them with foreign partners, and only $5 \%$ of firms abandoned such relationships during the same period. In 1996, 44.9\% of Slovenian firms were currently implementing some sort of subcontracting strategy ${ }^{1}$. Subcontracting has therefore been one of the most important strategy for Slovenian firms in the transition period.

Slovene industry is now at a crossroads. Top managers in the Slovene Companies spent a lot of time in the first three years of transition dealing with the short term issues of how to privatise the firm or how to survive. In the second stage of transition (1994-1998) they have focused on the long term strategic questions such as market and product development, recruitment and development of personnel, quality control and cost reduction. The majority of Slovenian firms is now attempting to find a niche in the global economy. Because of the marginal labour cost advantage of the Slovenian economy, Slovenian firms are trying to compete on the basis of product quality, reliability of supply and competence skills of workers. Low costs were only the third most important factor determining the competitive advantage of Slovenian enterprises.

\subsection{The process of privatisation, legislation and the role of different institutions determining mergers and acquisitions}

The privatisation concept in Slovenia was a compromise between many proposed concepts. Its main characteristics were (Kušar et al., 1993): a combination of free distribution of shares and commercial privatisation, a flexible and multitrack approach, immediate transformation of all companies into companies with known owners, followed by gradual real privatisation,

\footnotetext{
${ }^{1}$ The most frequently used forms of subcontracting relationships implemented by Slovenian enterprises were: long range production co-operation ( $46.2 \%$ of enterprises), »lohn arbeit« (36.6\% of enterprises), licence co-operation ( $26.9 \%$ of enterprises) and joint venture $(25 \%)$.
} 
decentralisation and supervision of the preparation of transformation programs and an active role of specialised government institutions in the case of commercial privatisation.

The Privatisation Law provides several methods of transformation. Companies were free to choose the method, or combination of methods, that suited them, but the overall transformation program had to be approved by the Agency for Privatisation. The two following methods were frequently used and they enabled the employees to take control of the company and become majority owners:

1. Internal distribution of shares to employees in exchange for ownership certificates (this was limited to 20 percent of the total shares of the company).

2. Internal buyout of shares at a 50 percent discount, which was limited to 40 percent of the shares of the social capital. The employees were also allowed to take such ownership stake gradually by paying in four year instalments.

Table 2: Number of Companies and the Share of Privatised Social Capital in the Companies with Internal and External Owners

\begin{tabular}{|l|c|c|}
\hline Category & $\begin{array}{c}\text { Share of companies } \\
\text { which went through } \\
\text { ownership transformation }\end{array}$ & $\begin{array}{c}\text { Share of social capital } \\
\text { which was privatised in } \\
\text { the ownership } \\
\text { transformation process }\end{array}$ \\
\hline $\begin{array}{l}\text { Companies in which } \\
\text { internal owners possess at } \\
\text { least 50\% of stocks }\end{array}$ & 76.7 & 43.7 \\
\hline $\begin{array}{l}\text { Companies in which } \\
\text { external owners possess } \\
\text { at least 50\% of stocks }\end{array}$ & 23.3 & 56.3 \\
\hline Total & 100 & 100 \\
\hline
\end{tabular}

Source: Ministry of Economic Affairs (March 1998).

Employees therefore had a possibility to become majority stakeholders by paying very favourable prices for stocks and by investing free certificates in their company. The consequence is that in the majority of enterprises which went through the ownership transformation, the internal owners possess the control share of stocks (See Table 2).

The ownership structure is therefore diversified among different individual stakeholders: employees, retired persons and family members of the employees. It is expected that these stakeholders will sell their shares in the near future. Based on annual accounts and other data operating characteristics of enterprises 
with internal and external owners in the transition period in Slovenia, we may conclude the following (Simoneti et al., 1998):

- enterprises with external owners outperform companies with internal owners,

- enterprises with internal owners have problems with cost control,

- enterprises with external owners are more capital intensive with higher assets per employee, and have higher turnover per employee compared with enterprises with internal owners,

- enterprises with internal owners have smaller added value per employee,

- enterprises with external owners have less debt.

Most Slovenian firms need strategic partners in order to compete in global markets. Therefore we may expect the consolidation of ownership in the near future through the acquisitions of control shares which are now, in many cases, owned internally. The first sign of that process is the decreasing number of individual stockholders in the companies which are already on the stock exchange (See Table 3).

The person or company which acquires a share in a joint stock company's voting stock so that this stock, together with other existing securities in its portfolio, ensures it a voting right of no less than $25 \%$, shall submit a public take-over bid to acquire these securities. The take-over bid shall also be made by a person or entity which has already acquired less than $45 \%$ of the value of securities and which has acquired an additional $5 \%$ of securities on the completion of its takeover bid. Prior to submitting the take-over bid, the bidder shall announce his intention of submitting a take-over bid to the Securities and Exchange Agency, which has the crucial regulation role of the acquisition process in Slovenia. The take-over prospectus shall also be sent to the stock exchange, the Central Clearing and Depository Corporation and to the competent authority for the protection of competition (The Official Gazette of Republic of Slovenia, 1992, 1993).

Legal regulations, lack of appropriate skills and financial resources, regulations of the Slovenian central bank, political impediments and negative attitude by the local community are the most common factors that negatively affect the development of the acquisition strategy. On the other hand, I expect that diversified ownership structure will accelerate the acquisition process in Slovenia in the near future because the heterogeneous group of owners don't have the strategic interest to maintain their stakes in enterprises. 
Table 3: The Number of Stockholders in Slovenian Companies ${ }^{2}$

\begin{tabular}{|c|c|c|c|c|c|c|}
\hline $\begin{array}{l}\text { Date of } \\
\text { issue }\end{array}$ & Company & $\begin{array}{l}\text { At the date } \\
\text { of issue }\end{array}$ & 1.1.1998 & 1.6 .1998 & 30.9.1998 & $\begin{array}{c}\text { Decrease } \\
\text { (\%) }\end{array}$ \\
\hline 15.11 .1995 & Kolinska & 7,297 & 4,999 & 4,680 & 4,601 & 36.9 \\
\hline 15.12 .1995 & PS Mercator & 63,020 & 31,283 & 29,899 & 28,277 & 55.1 \\
\hline 8.3 .1996 & $\begin{array}{l}\text { Tovarna } \\
\text { sladkorja Ormož }\end{array}$ & 1,785 & 368 & 326 & 321 & 82.0 \\
\hline 20.3 .1996 & Droga Portorož & 8,042 & 5,602 & 4,721 & 4,564 & 43.2 \\
\hline 2.4 .1996 & Slovenijales & 5,956 & - & 3,846 & 3,726 & 37.4 \\
\hline 18.4 .1996 & $\begin{array}{l}\text { Kompas Hoteli } \\
\text { Kranjska gora }\end{array}$ & 1,247 & 842 & 806 & 794 & 36.3 \\
\hline 26.4.1996 & Loka & 2,426 & 2,169 & 1,984 & 1,773 & 26.9 \\
\hline 6.5 .1996 & Lek A & 46,305 & 26,762 & 23,539 & 23,887 & 48.4 \\
\hline 22.5 .1996 & Rudis Trbovlje & 1,168 & 1,046 & 1,019 & 987 & 15.5 \\
\hline 22.5 .1996 & Lisca Sevnica & 3,209 & 2,627 & 2,309 & 1,636 & 49.0 \\
\hline 24.6 .1996 & Helios Domžale & 4,165 & 3,437 & 3,124 & 3,002 & 27.9 \\
\hline 15.7 .1996 & Gea & 1,120 & 750 & 729 & 592 & 47.1 \\
\hline 29.7 .1996 & Luka Koper & 10,356 & 9,566 & 9,431 & 8,715 & 15.8 \\
\hline 17.12 .1996 & Istrabenz Koper & 32,374 & 28,257 & 27,319 & 26,700 & 17.5 \\
\hline 6.1 .1997 & $\begin{array}{l}\text { Krka Novo } \\
\text { Mesto } \\
\end{array}$ & 90,734 & 74,192 & 69,259 & 67,769 & 25.3 \\
\hline 6.2 .1997 & $\begin{array}{l}\text { Radenska } \\
\text { Radenci }\end{array}$ & 17,126 & 15,445 & 12,561 & 12,090 & 29.4 \\
\hline 18.2.1997 & Petrol Ljubljana & 95,443 & 77,192 & 73,472 & 70,417 & 26.2 \\
\hline 12.3 .1997 & Jata Reja & 1,884 & 1,754 & 1,644 & 1,530 & 18.8 \\
\hline 27.10 .1997 & Potrošnik Celje & 1,210 & 916 & 849 & 825 & 31.8 \\
\hline 7.11 .1997 & Swaty & 1,532 & 1,295 & 1,226 & 1,149 & 25.0 \\
\hline 22.12 .1997 & $\begin{array}{l}\text { Fructal } \\
\text { Ajdovščina } \\
\end{array}$ & 6,672 & 6,620 & 6,148 & 5,909 & 11.4 \\
\hline- & Total & 403,071 & - & 278,891 & 269,264 & 33.2 \\
\hline
\end{tabular}

Source: Calculated from data supplied by the Central Clearing and Depository Corporation of Slovenia.

2 All companies were randomly selected from the list of companies that went through the ownership transformation process and are now listed on the Slovenian Stock Exchange. 
Table 4: The Relative Importance of Factors that Decrease the Number of Acquisitions in Slovenia

\begin{tabular}{|l|c|c|}
\hline Factor & Mean weighted score & Standard deviation \\
\hline Diversified ownership structure & 3.81 & 1.12 \\
\hline Legal regulations & 3.35 & 1.04 \\
\hline $\begin{array}{l}\text { Lack of appropriate skills and } \\
\text { human resources }\end{array}$ & 3.26 & 1.02 \\
\hline Regulations of the Central bank & 3.09 & 1.17 \\
\hline $\begin{array}{l}\text { Financial institutions are not } \\
\text { prepared to finance acquisitions }\end{array}$ & 2.87 & 1.01 \\
\hline Political impediments & 2.78 & 1.12 \\
\hline High transaction costs & 2.71 & 1.14 \\
\hline $\begin{array}{l}\text { Negative attitude by the local } \\
\text { community }\end{array}$ & 2.69 & 0.95 \\
\hline $\begin{array}{l}\text { Securities and Exchange } \\
\text { Agency }\end{array}$ & 2.53 & 1.01 \\
\hline
\end{tabular}

Note: 1) A five point scale was used in the assessment: 1- no importance, 5-very high importance

\section{Motives for the acquisition of enterprise}

\subsection{Overview of the most important motives for acquiring a company}

We can separate acquisitions into three main types: horizontal, vertical and conglomerate. A horizontal acquisition involves two firms operating and competing in the same kind of business activity. Although these acquisitions would generally benefit from large scale operation, not all horizontal acquisitions benefit from economies of scale. Vertical acquisitions occur between firms in different stages of production operation. A conglomerate acquisition involves firms engaged in unrelated types of business activity.

A number of hypotheses have been proposed to explain why acquisitions occur. These hypotheses can be broadly categorised as being of two types: value maximising and non-value maximising theories. The former postulate assumes that acquisitions are motivated by maximising the value of the firm to stockholders, whereas the latter propose that managers of bidding firms embark 
on acquisitions to maximise their own utility at the expense of stockholders (Seth, 1990, p.100). Conversely, Weston, Chung and Hoag identify seven hypotheses: the efficiency hypothesis, information and signalling, agency problems and managerialism, the free cash flow hypothesis, market power, taxes and redistribution hypothesis (Weston et al., 1990, p. 191). Davidson defines five main types of acquisitions regarding motives: those intended to spread risk/enter new markets, those intended to achieve a better return on financial assets, acquisitions intended to achieve a better return on marketing assets, those intended to be defensive and those intended to be synergistic (Davidson, 1987, p. 367-368). I strongly believe that the majority of acquisitions cannot be explained by only one hypothesis or motive. Factors determining the motive for acquisition over other corporate strategies (greenfield or joint ventures) could be different (i.e. the acquired company's market share, the acquired company's trademark or/and supply network, favourable price of the acquired company, acquisition price plus restructuring costs lower than greenfield investment).

The acquiring company may try to exploit different synergies that exist between the acquiring and the acquired company. Synergy exists in an acquisition when the value of the combined entity exceeds the sum of the values of the two individual firms. Synergies can be very different; therefore, we can usually identify multiple motives of acquiring companies for the development of the acquisition strategy. The question is whether motives for acquisitions in economies in transition are similar to those in developed economies. I expected that the motive described as »low price of the target company increased for restructuring costs « was more important in economies in transition than in developed economies.

In his study, Porter has identified four concepts of corporate strategy that have been put into practice: portfolio management, restructuring, transferring skills and sharing activities (Porter, 1987, p. 49). These concepts are not always mutually exclusive, but each of them rests on a different mechanism by which the corporation creates a shareholder value and each requires the diversified company to manage and organise itself in a different way. The first two concepts require no connection among business units, the second two depend on them. Acquisitions are the most popular strategy used to enter into new industries. These four concepts of corporate strategy are expected to be a frame for acquisition planning and implementation in economies in transition also.

Recent studies have found that we should identify the roots of competitive advantage of a firm in its core competencies (Prahalad, Hamel, 1990, p. 79-91). Therefore, acquiring firms try to develop their core competencies through the acquisition strategy of target companies. 


\subsection{Factors determining an acquiring company's decision to acquire a target company in Slovenia}

The managing directors identified various possible domestic and foreign acquiring institutions that could acquired their companies (See Table 5 and 6). According to the research, Slovenian investment funds and competitors are the most relevant acquiring domestic institutions. In contrast, foreign competitors and business partners are the most relevant acquiring foreign institutions. No institutions could be exposed as predominant, which is probably a consequence of the Slovenian privatisation route.

Table 5: Possible Domestic Acquiring Institutions in Slovenia

\begin{tabular}{|l|c|c|}
\hline Institution & Mean weighted score & Standard deviation \\
\hline Investment founds & 2.57 & 1.06 \\
\hline Competitors & 2.51 & 1.25 \\
\hline $\begin{array}{l}\text { Domestic acquiring institutions } \\
\text { in general }\end{array}$ & 2.26 & 1.14 \\
\hline Banks & 2.04 & 0.99 \\
\hline Business partners & 2.02 & 1.09 \\
\hline Stock-brokers houses & 1.88 & 1 \\
\hline Other firms & 1.84 & 1.02 \\
\hline State funds & 1.78 & 0.87 \\
\hline Other financial institutions & 1.75 & 0.88 \\
\hline Insurance companies & 1.63 & 0.79 \\
\hline Individuals from Slovenia & 1.59 & 0.89 \\
\hline Government & 1.46 & 0.73 \\
\hline
\end{tabular}

Note: 1) A five point scale was used in the assessment: 1- impossible, 5-definetly

The importance of motives for the acquisition of their companies were also assessed by the managing directors (See Table 7). Synergies created by sharing activities are the most important motive. The ability to share activities is a potential basis for acquisition, because sharing activities often enhances 
Table 6: Possible Foreign Acquiring Institutions in Slovenia

\begin{tabular}{|l|c|c|}
\hline Institution & Mean weighted score & Standard deviation \\
\hline Competitors & 2.75 & 1.17 \\
\hline Business partners & 2.42 & 1.13 \\
\hline $\begin{array}{l}\text { Other companies } \\
\text { conglomerates) }\end{array}$ & 2.2 & 1.14 \\
\hline Foreign acquirers in general & 2.19 & 1.01 \\
\hline Investment companies & 1.9 & 0.94 \\
\hline Individuals abroad & 1.7 & 0.88 \\
\hline Other financial institutions & 1.68 & 0.79 \\
\hline Banks & 1.66 & 0.84 \\
\hline
\end{tabular}

Note: 1) A five point scale was used in the assessment: 1- impossible, 5-definetly

competitive advantage by lowering costs or raising differentiation. Sharing can lower costs if it achieves economies of scale, boosts the efficiency of utilisation or helps a company move more rapidly down the learning curve. Sharing must involve activities that are significant to competitive advantage. Entering the Slovenian market is the second most important motive. According to the research in 1995 that examined factors which determine foreign investor's decision to acquire a Slovenian company, this motive was the third most important (Rojec et al., 1995, p. 179). Regarding the small Slovenian market, this could be unexpected; however, this result could be explained by the fact that Slovenian firms are the starting point for other Central European markets.

The low price of the target company combined with inefficient management and selling the acquired company by parts (respectively the third, eighth and tenth most important motives) are the basis for the restructuring strategy of the acquiring firms. This strategy seeks out undeveloped, struggling or threatened target firms. The acquiring firm intervenes by shifting strategy, changing the management team and infusing new technology. Regarding the transition period and the relatively undeveloped capital market, these three motives were expected to be important.

Strategic realignment to the changing environment is the factor that determines the acquisition strategy in Slovenia, but it plays a smaller role than could be expected. The globalisation and integration of the Slovenian economy are still not dominant factors. Diversification of business activities is a relatively 
unimportant motive; that was unexpected. According to the Porter study of 33 prestigious U.S. companies, each company entered an average of 80 new industries and 27 new fields. Just over $70 \%$ of the new entries were acquisitions, $22 \%$ were start-ups, and only $8 \%$ were joint ventures (Porter, 1987, p. 45). Entry into new product-markets, which represents diversification for the existing firm, may provide an important source of future growth and profitability. Acquisitions are especially attractive when the key parameters for success in the new business field are intangibles, such as patents, product image and R\&D skills that may be difficult to duplicate by internal development within reasonable cost and time scales. Acquiring patents and licences was assessed in this research as an unimportant motive (with weighted average score 1.53). Such assessment is the result of the fact that most Slovenian companies still possess neither patents nor licences that could be a predominant competitive factor in determining competitive advantage.

$25.8 \%$ of Slovenian firms that were included in the sample intend to acquire other company in the near future. The managing directors of these firms were asked to define the factors that determine the choice to acquire other company (See Table 8). The objective of increasing the market share is, in almost all cases, present as one of the motives for the development of the acquisition strategy. The Slovenian domestic market is relatively small. Slovenian enterprises have at first implemented the restructuring of their sales market by strengthening their sales on the small Slovenian market. Later, the firms which have enjoyed the largest shares of sales on the Slovenian market have gradually started to acquire substitute markets (Pučko et al., 1996, p. 467). The PIMS data showed that operating costs are inversely related to relative market share ${ }^{3}$. The differences do not appear to be as large as has been assumed in some versions of strategy analysis, based on the experience curve (Buzzell, 1981, p. 45) ${ }^{4}$. In spite this fact, the differences in costs are significant, and this contradicts the assumption that costs vary only slightly, which underlies stochastic models of business growth. Relative market share is a more direct measure of relative experience in immature markets than it is in older markets, where there has

${ }^{3}$ The PIMS program (Profit Impact of Market Strategies) was conducted by the Strategic Planning Institute, a non-profit research organisation in which more than 200 corporations participated.

${ }^{4}$ A competitor with a market share twice as large as his leading rival might have been expected to have costs $20-30 \%$ lower than those of the rival firms, based on the typical slope of long -run experience curves. Buzzell argued that the actual difference is more likely to be $5-10 \%$. 
Table 7: Motives of the Potential Foreign and Domestic Acquiring Enterprises for the Acquisitions of Slovenian firms

\begin{tabular}{|c|c|c|}
\hline Motives of the acquiring enterprises & Mean weighted score & Standard deviation \\
\hline 1. Synergies by sharing activities & 3.27 & 1.14 \\
\hline 2. Fast entering Slovenian market & 3.04 & 1.34 \\
\hline 3. Low price of the target firm & 2.96 & 1.2 \\
\hline 4. Financial synergies & 2.9 & 1.18 \\
\hline $\begin{array}{l}\text { 5. Excess cash flow of the } \\
\text { acquiring firm }\end{array}$ & 2.61 & 1.13 \\
\hline $\begin{array}{l}\text { 6. Strategic realignment to } \\
\text { changing environment }\end{array}$ & 2.6 & 1.06 \\
\hline $\begin{array}{l}\text { 7. Speculative (to sell the acquired } \\
\text { firm to the next bidder) }\end{array}$ & 2.55 & 1.14 \\
\hline $\begin{array}{l}\text { 8. Acquisition and selling out } \\
\text { acquired company by parts }\end{array}$ & 2.53 & 1.15 \\
\hline 9. Lower labour costs & 2.51 & 1.18 \\
\hline $\begin{array}{l}\text { 10. To change management of the } \\
\text { acquired company }\end{array}$ & 2.43 & 1.01 \\
\hline $\begin{array}{l}\text { 11. To change the board of the } \\
\text { acquired company }\end{array}$ & 2.34 & 1.04 \\
\hline $\begin{array}{l}\text { 12. Liquidation of your company as } \\
\text { a competitor on the Slovenian } \\
\text { market }\end{array}$ & 2.27 & 1.22 \\
\hline $\begin{array}{l}\text { 13. Diversification of business } \\
\text { activities }\end{array}$ & 2.23 & 1.04 \\
\hline $\begin{array}{l}\text { 14. Liquidation of your company as } \\
\text { a competitor on the world } \\
\text { market }\end{array}$ & 2.15 & 1.14 \\
\hline 15. Tax motives & 2.04 & 1.07 \\
\hline 16.Megalomania and self-fulfilment & 2.04 & 1.11 \\
\hline
\end{tabular}

Note: 1) A five point scale was used in the assessment: 1- no importance, 5-very high importance

been more opportunity for changes in competitive position to occur. Therefore costs are more strongly related to relative market share for businesses competing 
in less mature markets than they are in mature markets. Cost differentials among competitors tend to diminish as a market matures, because smaller firms are able to imitate market leaders, processes and equipment.

Table 8: Motives of the Slovenian Managing Directors for the Acquisitions of other Companies in the Near Future

\begin{tabular}{|l|c|}
\hline Motives & Share of firms (in \%) \\
\hline To increase market share & 87.5 \\
\hline Synergies and economies of scale & 62.5 \\
\hline Entering new geographic markets & 56.3 \\
\hline $\begin{array}{l}\text { Entering new market segments- } \\
\text { diversification }\end{array}$ & 56.3 \\
\hline Fast growth of the firm & 37.5 \\
\hline To invest excess cash flow into new firm & 31.3 \\
\hline $\begin{array}{l}\text { 1. Low price of the target company } \\
\text { 2. Financial synergies }\end{array}$ & 31.3 \\
\hline 3. To change inefficient management of \\
the target company
\end{tabular}

Slovenian firms, which are mainly dependent on domestic market, have problems in exploiting economies of scale. A high relative market share on the Slovenian market does not always represent a sufficient volume of production that allows for competition with foreign firms which are much larger than the majority of Slovenian firms ${ }^{5}$. On the other hand, the competent authority for the protection of competition in Slovenian market can very easily prevent each acquisition or merger when the consequence of such an acquisition or merger would be the control of at least $50 \%$ of the Slovenian market. Slovenian industry is in the restructuring process that should be implemented through mergers and acquisitions in order to improve efficiency as well. Mergers and acquisitions of Slovenian firms are »conditio sine qua non« of restructuring processes in global

\footnotetext{
${ }^{5}$ In the latest period, a well known case of acquisition is in the Slovenian food processing industry, where one firm acquired another in order to develop the consolidation strategy to improve cost efficiency. The main motive for such an acquisition is due to the changing business environment. Slovenia will have to liberalise its import regime because of the integration with other European markets. The Slovenian food processing industry is therefore under strong competitive pressure of foreign European firms. This acquisition can not be categorised as one which could restrict competition in the Slovenian market in spite of the fact that at the moment, the acquiring firm controls more than $50 \%$ of the market.
} 
industries where firms can improve their competitive position by combining their activities on the global level.

Synergies and economies of scale are proved to be very important in $62.5 \%$ of firms, whereas entering new geographic markets and diversification of business activities are important as motives in $56.25 \%$ of firms that intend to acquire another firm. Only $31.3 \%$ of potential acquiring firms described a low price of the target company as a relevant motive determining the decision for acquisition.

Target companies have different relations with Slovenian firms that intend to acquire them (See Table 9). Most of them are competitors or buyers, domestic or foreign. The suppliers, distributors and an unrelated companies are less frequent target companies. This result is quite consistent with the motives for acquisitions where a larger market share and different synergies between acquiring and target company are dominant.

Table 9: Type of Company that Slovenian Companies Intend to Acquire (number of companies)

\begin{tabular}{|l|c|c|}
\hline Target company & Domestic & Foreign \\
\hline Supplier & 1 & - \\
\hline Buyer & 6 & 1 \\
\hline Distributor & 2 & 1 \\
\hline Competitor & 5 & 3 \\
\hline Unrelated company & 2 & - \\
\hline
\end{tabular}

\section{Conclusion}

I believe that acquisitions of enterprises will accelerate the restructuring and integration processes of the Slovenian economy into the European Community and improve the competitive position of Slovenian firms in the global markets. Slovenian industry is now at a crossroads. In the first three years of transition top managers in Slovene companies spent a lot of time dealing with the short term issues of how to privatise the firm or how to survive. In the second stage of transition (1994-1998) they have focused on the long term strategic questions such as market and product development, recruitment and development of personnel, quality and cost reduction. The majority of Slovenian firms is now in an attempt to find a niche in the global economy.

The ownership structure in Slovenian enterprises is diversified among different individual stakeholders: employees, retired persons and family members of the employees. It is expected that these stakeholders will sell their shares in the near future. We may expect the consolidation of ownership in the near future through the acquisitions of control shares which are now in many cases owned by 
internal owners. The first sign of that process is, the decreasing number of individual stockholders in the companies which are already on the stock exchange.

The Slovenian Take-over Act has two significant characteristics compared with the acts in developed economies, which are both consequences of the privatisation process in Slovenia. The firs characteristic is that, the Slovenian Take-over Act shall not apply to some institutions which have significant roles in the privatisation process and which are of special public interest. The second is that when the capital stock value of the company-issuer of securities which has undergone ownership transformation exceeds US \$ 5 million on the company's legal registration, the acquisition of more than $25 \%$ of shares of individual issuers shall be subject to the approval of the Slovenian Government.

Legal regulations, lack of appropriate skills and financial resources, regulations of the central bank, political impediments and negative attitude of the local community are the most usual factors that have a negative effect on the development of the acquisition strategy. On the other hand, I expect that diversified ownership structure will accelerate the acquisition process in Slovenia in the near future, because the heterogeneous group of owners do not have the strategic interest to maintain their stakes in enterprises.

According to the research, Slovenian investment funds and competitors are the most relevant acquiring domestic institutions, whereas foreign competitors and business partners are the most relevant acquiring foreign institutions. No institutions could be exposed as predominant, which is probably a consequence of the Slovenian privatisation route. Synergies created by sharing activities are the most important motive for the acquisition of the companies that were included into the research sample. Entering Slovenian market is the second most important motive. The low price of the target company combined with inefficient management and selling an acquired company by parts (respectively the third, eighth and tenth most important motives) are the basis for the restructuring strategy of the acquiring firms. Regarding the transition period and relatively undeveloped capital market, these three motives were expected to be the most important.

Strategic realignment to fit the changing environment is the factor that determines the acquisition strategy in Slovenia, but is not so strong as could be expected. The globalisation and integration of the Slovenian economy are still not dominant factors. The acquisition of patents and licences was assessed in this research as an unimportant motive. Such assessment is the result of the fact that most of Slovenian companies still do not possess patents or licences that could be a predominant competitive factor determining competitive advantage.

$25.8 \%$ of Slovenian firms that were included in the sample intend to acquire another company in the near future. Objective to increase the market share is, in 
almost all cases, present as one of the motives for the development of the acquisition strategy. Synergies and economies of scale are proved to be very important in $62.5 \%$ of firms, whereas entering new geographic markets and diversification of business activities are important as motives in $56.25 \%$ of firms that intend to acquire another firm. Only $31.3 \%$ of potential acquiring firms described a low price of the target company as a relevant motive that determines the decision for acquisition. Most target companies are competitors or buyers, either domestic or foreign. Suppliers, distributors and unrelated companies are less frequent target companies. This result is quite consistent with the motives for acquisitions where larger market share and different synergies between acquiring and target company are dominant.

\section{References}

Bilten BS (1998), Bank of Slovenia, Ljubljana, pp 68.

Ekonomsko ogledalo (1997), UMAR, Ljubljana, pp 14.

Ekonomsko ogledalo (1999), UMAR, Ljubljana, pp 15.

Buzzell Robert (1981): Are there Natural Market Structures? Journal of Marketing, No. 1, pp 42-51.

Central Clearing and Depository Corporation of Slovenia (1998), Ljubljana

Davidson Hugh (1987): Offensive marketing, Penguin books, Harmondsworth.

Kušar I., Rojec M. (1993): Foreign Investment and Privatisation in Slovenia, Agency for Restructuring and Privatisation, Ljubljana.

Law on Ownership Transformation of Socially Owned Companies. The Official Gazette of Republic of Slovenia: N. 55/92, N. 7/93, N. 31/93 and N. 43/93, Ljubljana.

Ministry of Economic Affairs Republic of Slovenia, (March 1998), Ljubljana.

Porter Michael (1987): From competitive advantage to corporate strategy, Harvard Business Review, No. 3, pp 43-59.

Prahalad C.K., Hamel Gary (1990): The Core Competence of the Corporation, in: Harvard Business Review, No. 3, pp 79-93.

Pučko Danijel, Lahovnik Matej (1996): Characteristics of Strategic Restructuring Processes in Slovenian Enterprises, in: Slovene Economic Review, No. 5-6, pp 464-479.

Rojec Matija et al. (1995): Foreign Direct Investment and Privatisation in Central and Eastern Europe- A Comparative Analysis of Concepts, Experiences and Policy Issues in the Czech Republic, Hungary, Poland and Slovenia, ACE Research Project, Ljubljana.

Seth Anju (1990): Value Creation in Acquisitions: A Reexamination of Performance Issues, in: Strategic Management Journal, No. 2, pp 99-115.

Simoneti Marko et al. (1998): Some Operating Characteristics of Enterprises with Internal and External Owners, in: Slovene Economic Review, No. 1-2, pp 130-148.

Statistical Yearbook RS (1997), Ljubljana, pp 62.

Takeover Act. The Official Gazette of Republic of Slovenia: N. 47/1997, Ljubljana. 
Weston Fred J., Chung Kwang S., Hoag Susan E. (1990): Mergers, Restructuring and Corporate Control, Prentice-Hall, New Jersey. 